\title{
Research into the moisture influence on the physical-chemical tuff-stone characteristics in basalt quarries of the Rivne-Volyn region
}

\author{
Yevhenii Malanchuk ${ }^{1}$, Valerii Korniienko ${ }^{2 *}$, Larisa Malanchuk $^{3}$, and Vitalii Zaiets ${ }^{2}$ \\ ${ }^{1}$ National University of Water Management and Nature Resources Use, Department of Automation, \\ Electrical Engineering and Computer-Integrated Technologies, 11 Soborna St., 33028 Rivne, Ukraine \\ ${ }^{2}$ National University of Water Management and Nature Resources Use, Department of Development \\ of Deposits and Mining, 11 Soborna St., 33028 Rivne, Ukraine \\ ${ }^{3}$ National University of Water Management and Nature Resources Use, Department of Public \\ Administration, Documenting and Information Activities, 11 Soborna St., 33028 Rivne, Ukraine
}

\begin{abstract}
This paper studies the rock mass stress state of deposits under highland conditions, depending on the geological structure of a particular rock mass area, the tectonic field of stresses and the region relief. This study is aimed to develop an experimental method for assessing and monitoring the properties and state of the rock mass adjacent to mine workings. Experimental studies are performed through stresses measurements in-situ. Based on research results, it has been revealed that the geological structures, tectonic fields of stresses and the earth's surface relief of the deposit normally reflect the values and direction of the main stresses acting in the rock mass. These patterns can be used to predict and assess the stress state of the rock mass. During the rock mass stress state assessment, quantitative dependences have been obtained for determining the stress tensors conditioned by the overlying rocks weight, tectonics and fracturing, and the deposit surface relief The research results make possible to assess the nature of the stresses distribution, to identify the areas of reduced, equal, increased and maximum stresses concentration of the virgin rock mass, as well as to increase the efficiency of the geoacoustic control developed by the authors for the state of the rock mass adjacent to mine working.
\end{abstract}

\section{Introduction}

The growing tuff-stones consumption in the national economy requires their additional study, as well as improvement of production and processing technology. Their rich microelement composition in the form of native copper, iron, titanium, etc. allows to use them as a valuable raw material for industry. Unique sorption and selective abilities represent wide opportunities for using tuff-stone in many economy sectors. The zeolitesmectite tuff-stones, the reserves of which have been explored in the Rivne-Volyn region (Ukraine) and that are rich in deposits discovered by dozens of wells and several basalt

*Corresponding author: kvja@i.ua 
quarries, are of particular attention $[1,2]$.

The surface conditions of the tuff-stone occurrence enable its mining by both quarry and downhole methods. The downhole method of mining is possible without significant costs for overburden mining, as it is noted in the following publications [3, 4].

A number of industrial experiments, the experience of using tuff-stone in agriculture, cattle farming, construction, recent studies on its microelement composition and revealing of a high content of metals valuable for industry, as well as its availability and huge reserves for mining - all this indicates that the tuff-stone is a valuable raw material [5].

At the same time, for the integrated mining and processing of mineral raw materials, it is necessary to solve a number of geotechnological problems related to improving the mining system $[6-8]$, optimizing planning decisions $[9,10]$, taking into account the ecological component of minerals mining and processing [12-16], as well as determining the effect of moisture together with its filtration processes on the physical-chemical properties of mineral raw materials [17 - 20]. Particular attention should be paid to modern technologies for the integrated mining and processing of raw materials based on the latest methods $[21-23]$.

The relevance of research into the moisture influence on the tuff-stones strength characteristics is to identify the dependences of their weakening degree on the moisture exposure duration and determine the water absorption coefficient. These are important indicators for one of the geotechnological mining methods with the use of hydraulic mining at the site of occurrence [24-26]. On the other hand, In case of the selective tuff-stone extraction from the quarry dumps, it is also necessary to study the issue of changing the physical-chemical characteristics of the rocks composing the dumps when they are moistened and then dehydrated [27 - 31].

The physical-chemical tuff-stones characteristics are not thoroughly studied. Given the tuff-stones diversity, the development of common indicators of their characteristics is impossible. Nowadays, an issue of the tuff-stones complex processing is becoming urgent, since they have a rich microelement composition and a large percentage of silicate mass [32 - 34]. All these elements are widely used in industry, agriculture, cattle farming and medicine. To extract them during the complex processing of mined rock mass, it is necessary to perform a number of technological operations for crushing, grinding, classifying and separating [35-37]. This requires knowledge of the physical and mechanical characteristics, especially strength, the moisture influence on the characteristics, as well as water absorption. Moreover, this is important not only at the stage of tuff-stone masses processing, but also at the stage of mining [38-41].

The specificity of the basaltic layer occurrence is in the form of a traprock formation, which consists of separate layers or interlayers in the basalt of lava-breccia and tuff-stone. In this case, the tuff-stone is either under the overburden basalt mass layer or is its underlying rock. In all these cases, when drilling the wells to break down the bench, after the explosion, the rock mass is a mixture of basalt, lava-breccia and tuff-stone. Given that the strength of these rocks is different, basalt, as the hardest, has the rock mass with greater lumpiness. Lava-breccia has a high level of fracturing and in terms of strength, it ranks by 2 times below than the basalt. Therefore, when blasting breakage, it retains lumpiness. However, the pieces' sizes are smaller than that of basalt, therefore, when being excavated, basalt is separated from the total mass and sent to a grinding-sorting factory for processing into various fractions of crushed stone. The remaining lava-breccia and tuff-stone are not marketable products and are shipped to the dump. In this case, tuff-stone, as the weakest rock, has smaller lumpiness [42-45].

The tuff-stone extraction from dumps is its most economic production, however, the implementation of this technology is difficult because of complexity in its separation from the total dump mass. Studies have shown that from 30 to 40 percent of the tuff-stone with 
various granulometric compositionn is in the dump, so the question of its extraction requires a search for solutions. The possible problem solution is in the idea that the tuffstones in operating quarries are of lower strength in relation to the tuff-stone mined underground. This is conditioned by the fact that they are constantly exposed to explosions in the quarry and have high fracturing level. In addition, at any time of the year they are exposed to moisture influence from precipitation, which further weakens them.

The solution to this idea is based on the author's research related to the study of amber hydraulic mining and determination of its physical-chemical properties [46, 47], as well as the study of phosphogypsum and basalt deposits in the Rivne region area [48 - 51].

The objective of research is to determine the moisture influence on the strength characteristics and the moisture absorption degree of deep-lying tuff-stones. According to the new patterns and dependences obtained, the values and directions have been scientifically determined of the main stresses action, as well as the zones of stresses manifestation. These patterns and dependences are valuable for designing and planning the development of mining operations.

\section{Methodology}

The Earth's crust is composed of rocks, diverse in origin and composition. This paper is focused on the hard rocks study.

Paper studies the tuff-stones characteristics in the Rivne region, which are identified during the basalts extraction in quarries or during the development of downhole hydraulic mining technology. As it is noted by the Rivne expedition geologists, the tuff-stones of this region have a zeolite-smectite base, and during their formation are exposed to hydrothermal transformations. The tuff-stone layers with a thickness of up to $150 \mathrm{~m}$, underlying the basalt mass and having a high density, are exposed to mine rock pressure and by strength are halfrock. The tuff-stone layers, cropping out to the day surface, have a low strength. According to the developments of basalt mining, it is known that all tuff-stones are prone to moisture influence, however, such an effect has not been quantified.

In the process of research, an experimental method is used to study the full-scale specimens of the tuff-stone in the form of geological samples cores after drilling the wells at depths in the range of $100-300 \mathrm{~m}$. Samples are taken from eleven wells. The initial weight of the samples $m$, the indenter impressing force $P_{0}$ on the press are fixed by a known methodology. The indenter tip, according to the methodology, has a cross-sectional area of $1.0 \mathrm{~mm}^{2}$, therefore, the sample resistance voltage value $\sigma$ has also been recorded on the device. After the samples are immersed into an aqueous medium, the time of exposure is recorded and the sample weight, the indentation force $P_{0}$, and voltage value $\sigma$ are determined on a staged basis.

\section{Results and discussion}

The obtained results analysis has shown that the tuff-stones absorb at an average of $12 \%$ water relative to the weight of a dry sample. In this case, their intense softening occurs due to the weakening of cementing zeolites and smectites. The greatest intensity of weakening occurs during the first $1.5-2.0$ hours of immersing the sample into water, and during the week the samples become so weakened that they begin to lose their shape. In Table 1, there are quantitative, weight and strength characteristics, as well as a temporary assessment of the state of samples held in water for a long time. These results are of practical interest when organizing the technological cycle of downhole hydraulic mining of tuff-stones. 
Table 1. Research results of the tuff-stones characteristics in case of increased humidity.

\begin{tabular}{|c|c|c|c|c|c|c|c|c|c|c|c|c|c|c|c|c|c|}
\hline \multicolumn{18}{|c|}{ The time of the sample exposure in water, $\min$} \\
\hline \multirow{2}{*}{$\begin{array}{l}\text { Well } \\
\text { depth } \\
\text { m }\end{array}$} & \multicolumn{3}{|c|}{0} & \multicolumn{3}{|c|}{90} & \multicolumn{3}{|c|}{180} & \multicolumn{3}{|c|}{300} & \multicolumn{3}{|c|}{1440} & \multicolumn{2}{|c|}{10080} \\
\hline & $\begin{array}{r}m, \\
\mathrm{~g}\end{array}$ & $\begin{array}{l}P_{0}, \\
\text { kgf }\end{array}$ & $\begin{array}{c}\sigma, \\
\mathrm{kg} / \mathrm{mm}^{2}\end{array}$ & $\begin{array}{c}m, \\
\mathrm{~g}\end{array}$ & $\begin{array}{l}P_{0}, \\
\mathrm{kgf}\end{array}$ & $\begin{array}{c}\sigma, \\
\mathrm{kg} / \mathrm{mm}^{2}\end{array}$ & $\begin{array}{c}m, \\
\mathrm{~g}\end{array}$ & $\begin{array}{l}P_{0}, \\
\mathrm{kgf}\end{array}$ & $\begin{array}{c}\sigma, \\
\mathrm{kg} / \mathrm{mm}^{2}\end{array}$ & \begin{tabular}{|c|}
$m$, \\
$\mathrm{g}$
\end{tabular} & $\begin{array}{l}P_{0}, \\
\mathrm{kgf}\end{array}$ & $\begin{array}{c}\sigma, \\
\mathrm{kg} / \mathrm{mm}^{2}\end{array}$ & $\begin{array}{c}m, \\
\mathrm{~g}\end{array}$ & $\begin{array}{l}P_{0}, \\
\text { kgf }\end{array}$ & $\begin{array}{c}\sigma, \\
\mathrm{kg} / \mathrm{mm}^{2}\end{array}$ & $\begin{array}{c}m, \\
\mathrm{~g}\end{array}$ & $\begin{array}{l}P_{0}, \\
\mathrm{kgf}\end{array}$ \\
\hline 252.8 & 27.2 & 60 & 17.14 & 28.4 & 8 & 2.286 & 28.6 & 6 & 2.0 & 29.0 & 5 & 1.14 & 29.2 & 4 & 1.14 & 29.4 & 2 \\
\hline 115.0 & 48.3 & 50 & 14.29 & 51.1 & 8 & 2.286 & 52.0 & ( & 2.0 & 52.6 & & 14 & 53.0 & & .14 & 53.7 & 2 \\
\hline 241.6 & 48.4 & 140 & 2 & 19.6 & 20 & 571 & 50.0 & 16 & 4. & 50.2 & 10 & 2.28 & 51.0 & & 2.28 & 51.5 & 3 \\
\hline 307.1 & 31.8 & 40 & 11.43 & 33.4 & 8 & 2.28 & 34.0 & & 2. & 34.6 & & 1.14 & 35.2 & & 14 & 35.8 & 2 \\
\hline 267.0 & 45.8 & 24 & 6.85 & 48.4 & 6 & 1.7 & 49.2 & 5 & 1.3 & 49.2 & 4 & 1.14 & 49.9 & 4 & 1.14 & \begin{tabular}{|l|}
50.4 \\
\end{tabular} & 2 \\
\hline 244.1 & 54.4 & 24 & 6.85 & 55.2 & 6 & 1. & 55.4 & 4 & 1. & 55.6 & & 0.57 & 55.8 & & 0.57 & 60.4 & 1.0 \\
\hline 288.1 & 65.0 & 40 & 11.43 & 96.3 & 8 & 2.28 & 70.2 & 6 & 2.0 & 70.4 & 5 & 1.14 & 70.6 & 4 & 1.17 & 72.0 & 2 \\
\hline 254.5 & 32.4 & 64 & 18.29 & 34.4 & 16 & 4.57 & 34.8 & 14 & 3.9 & 35.2 & 8 & & 35.8 & 6 & 7 & 36.0 & 3 \\
\hline 250.4 & 40.4 & 48 & 13.71 & 43.0 & 8 & 2.28 & 43.1 & & 2.1 & 43.2 & 5 & 0.85 & 43.4 & 3 & 0.85 & 45.1 & 1.5 \\
\hline 304.0 & 36.8 & 40 & 11.43 & 39.0 & 12 & 3.43 & 39.4 & & 2.9 & 40.1 & & & 41.0 & & .14 & 41.5 & 2 \\
\hline 247.0 & 52.8 & 40 & 11.43 & 55.8 & 6 & 1.7 & 56.8 & 4 & 1.3 & 57.6 & 3 & 0.85 & 60.2 & 3 & 0.85 & 60.8 & 1.5 \\
\hline
\end{tabular}

A graphical representation of experimental research on weakening the tuff-stone mined underground for samples of all eleven wells is presented in Fig. 1, and the kinetics of water absorption by the samples to saturation is shown in Fig. 2. Both processes have a relatively short period of time. It should be noted that the dispersion of initial strength $\sigma$ of the samples is explained not only by the different strength of the tuff-stone at the elevations of the samples taken or by any inclusions, but also by the presence of subsurface water, which the studied field is rich in. It is important to maintain the general tendency of the tuff-stone toward weakening in the aquatic environment and to determine the time of final weakening.

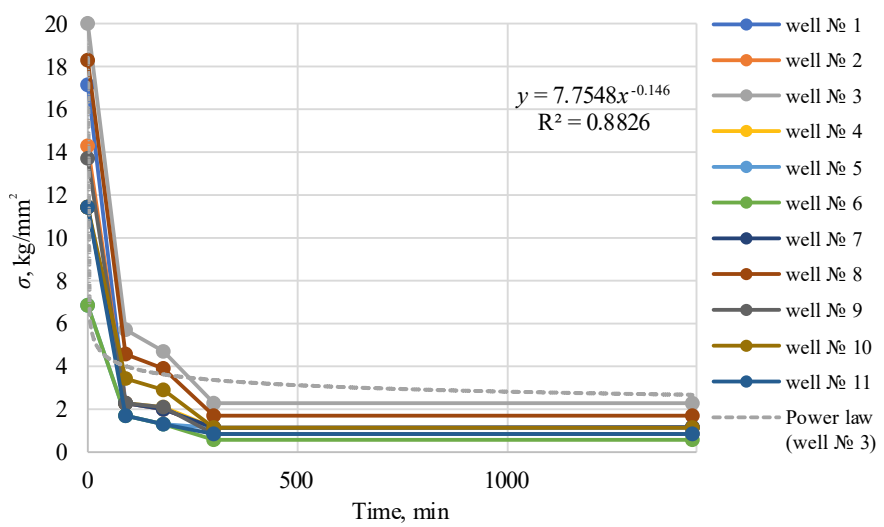

Fig. 1. Dependence of the tuff-stone samples contact strength on the time spent in water.

The process of samples water saturation over time is shown in Fig. 2 in the form of a coefficient of saturation resistance $k$, which is the ratio of the original dry sample $M_{0}$ mass to the mass of the sample exposed in water over specified time intervals $M_{i}\left(k=\frac{M_{0}}{M_{i}}\right)$. It can be seen from the figure that, despite the different intensity of water absorption by the samples, the general tendency to temporary saturation is remained. The absorbed water percentage is set by gravimetric method, which is important for determining its amount when supplied to the well for the tuff-stone weakening in the chamber. 


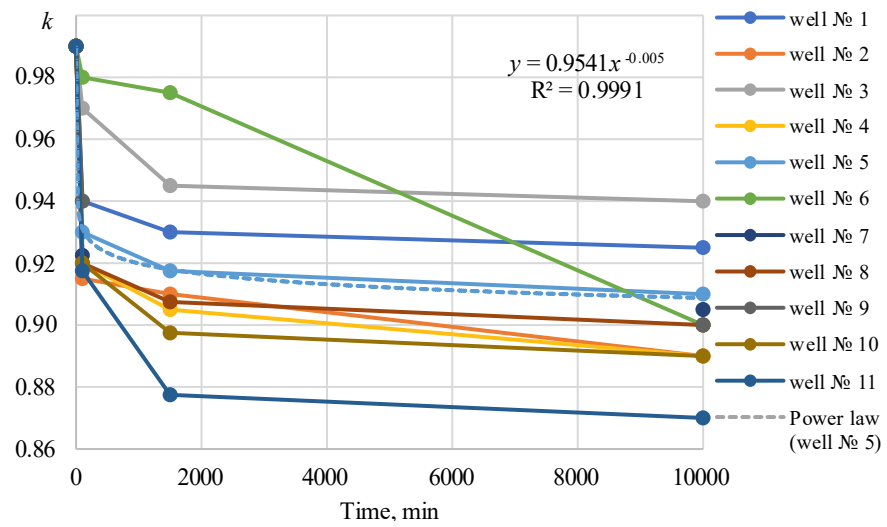

Fig. 2. Dependence of the moisture saturation resistance coefficient on the time spent by the tuffstone samples in water.

The empirical dependences of the tuff-stone samples contact strength on the time spent in water (1) and the moisture saturation resistance coefficient on the time spent by the tuffstone samples in water (2) have been also determined with sufficiently high values of the approximation reliability $\left(R^{2}\right) 0.88$ and 0.99 , respectively. Consequently, it is possible on their basis to perform predictive calculations with a sufficient degree of accuracy:

$$
\sigma=7.7548 \cdot t^{-0.146}
$$

where $t$ is the time spent by tuff-stone in water.

Thus, the tuff-stones, influenced by intensive wetting, are weakened up to $10-15$ times, lose the ability to restore their original strength after extraction from water and drying. Water absorption by the tuff-stone is at an average of $12 \%$ from the sample weight. This property is recommended to use in downhole hydraulic mining of the tuff-stones for increasing the well productivity and reducing the energy consumption during the process of the tuff-stone layer breakage by hydraulic monitors in the chamber. The application of this tuff-stones property is especially effective when using two neighbouring wells that work with counter faces along the tuff-stone pillar, as shown in Fig. 3.

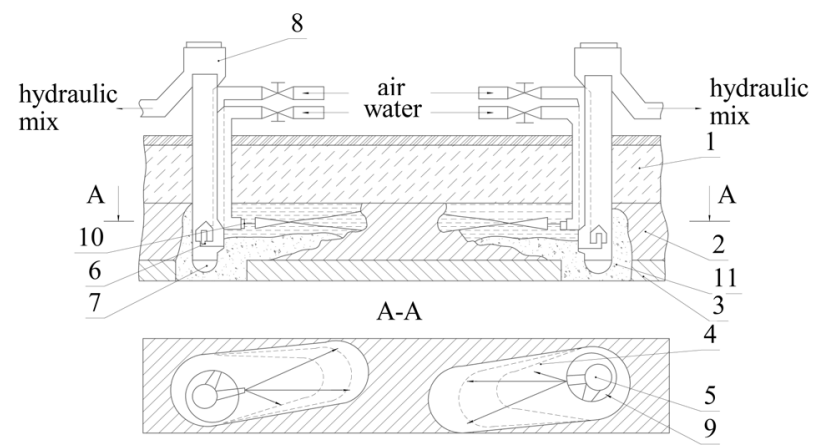

Fig. 3. Scheme for mining the tuff-stone extraction chamber with its preliminary weakening: 1 - roof; 2 -tuff-stone; 3 - chamber bottom; 4 - chamber; 5 - airlift system; 6 -airlift atomizers; 7 - suction pipe; 8 - air distributor; 9 - well casings; 10 - hydraulic monitor; 11 - hydraulic mixture.

The difference in the mining process according to this well-known scheme is that the hydraulic monitors do not work immediately along the tuff-stone layer with the prepared wells. Tuff-stone should be preliminary filled with water and kept in this state for at least 
7 - 10 days to weaken. Thereafter, the destruction by oncoming hydraulic monitors occurs much faster, with a large output of solid in the pulp, without the formation of arches and with less water pressure in the hydraulic monitors. In this case, the hydraulic monitors operate in the conditions of an immersed jet, which requires additional research and analysis of the power characteristics of the face destruction in the aquatic environment, as well as a quantitative assessment of water flow rate. Therefore, the main task is to determine the average flow rate in the stream and the flow rate of water in the jet section.

Laboratory research on the tuff-stone weakening in the aquatic environment has revealed that the tuff-stone mined in a quarry is destroyed much more intensively than that mined underground. Moreover, the destruction process depends on the granulometric composition of the tuff-stone, which affects the time and nature of its destruction. Pieces up to $20-25 \mathrm{~mm}$ in size after being held in water for $120-150$ hours completely disintegrate into small parts $(1.5-2.0 \mathrm{~mm})$, and pieces of $250-400 \mathrm{~mm}$ in size disintegrate into parts of $50-100 \mathrm{~mm}$, and, then, after repeated exposure in water, they break up into separate fine fractions. The research results of such a saturation are shown in Table 2, where the saturation process of filled with water tuff-stone samples with various weights is fixed in time. The full moisture saturation of the samples occurs after 120 hours, and small samples are saturated within $1-2$ hours. Table 3 presents the results of research on the time of samples dehydration after their saturation in water.

Table 2. Research results of the tuff-stone saturation with water.

\begin{tabular}{|c|c|c|c|c|c|c|c|}
\hline \multirow{2}{*}{$\begin{array}{c}\text { Time, } \\
\text { hours }\end{array}$} & \multicolumn{7}{|c|}{ Sample weight, kg } \\
\cline { 2 - 8 } & № 1 & № 2 & № 3 & № 4 & № 5 & № 6 & № 7 \\
\hline 0 & 0.052 & 0.106 & 0.348 & 0.681 & 1.025 & 2.18 & 3.347 \\
\hline 0.5 & 0.056 & 0.113 & 0.362 & 0.707 & 1.077 & 2.246 & 3.44 \\
\hline 1 & 0.058 & 0.116 & 0.363 & 0.708 & 1.089 & 2.275 & 3.473 \\
\hline 2 & 0.058 & 0.118 & 0.363 & 0.71 & 1.092 & 2.321 & 3.544 \\
\hline 3 & 0.058 & 0.124 & 0.364 & 0.714 & 1.097 & 2.336 & 3.548 \\
\hline 23 & 0.058 & 0.125 & 0.366 & 0.715 & 1.102 & 2.359 & 3.563 \\
\hline 68 & 0.058 & 0.125 & 0.368 & 0.718 & 1.104 & 2.365 & 3.594 \\
\hline 96 & 0.058 & 0.125 & 0.37 & 0.718 & 1.106 & 2.368 & 3.596 \\
\hline 120 & 0.058 & 0.125 & 0.37 & 0.718 & 1.106 & 2.368 & 3.596 \\
\hline
\end{tabular}

The dehydration process at room temperature $\left(24^{\circ} \mathrm{C}\right)$ occurs within $2-3$ hours for small tuff-stone pieces and within 140 - 150 hours - for large pieces. The one cycle of water exposure resulted in almost complete destruction of small tuff-stone fractions, and large ones broke down into $3-4$ parts. Therefore, $3-4$ cycles are necessary for their complete destruction.

Table 3. Research results of the tuff-stone dehydration.

\begin{tabular}{|c|c|c|c|c|c|c|c|}
\hline \multirow{2}{*}{$\begin{array}{c}\text { Time, } \\
\text { hours }\end{array}$} & \multicolumn{7}{|c|}{ Sample weight, $\mathrm{kg}$} \\
\hline & №1 & №2 & №3 & №4 & №5 & №6 & №7 \\
\hline 0 & 0.058 & 0.125 & 0.37 & 0.718 & 1.106 & 2.368 & 3.596 \\
\hline 1 & 0.054 & 0.116 & 0.364 & 0.716 & 1.102 & 2.343 & 3.568 \\
\hline 3 & 0.052 & 0.112 & 0.36 & 0.706 & 1.097 & 2.335 & 3.556 \\
\hline 6 & 0.052 & 0.111 & 0.357 & 0.702 & 1.09 & 2.329 & 3.532 \\
\hline 25 & 0.052 & 0.109 & 0.351 & 0.694 & 1.071 & 2.286 & 3.488 \\
\hline 30 & 0.052 & 0.107 & 0.35 & 0.691 & 1.066 & 2.281 & 3.48 \\
\hline 33 & 0.052 & 0.106 & 0.349 & 0.69 & 1.062 & 2.275 & 3.47 \\
\hline 50 & 0.052 & 0.106 & 0.348 & 0.684 & 1.05 & 2.248 & 3.438 \\
\hline 53 & 0.052 & 0.106 & 0.348 & 0.684 & 1.049 & 2.243 & 3.432 \\
\hline 118 & 0.052 & 0.106 & 0.348 & 0.684 & 1.025 & 2.228 & 3.372 \\
\hline 148 & 0.052 & 0.106 & 0.348 & 0.684 & 1.025 & 2.18 & 3.347 \\
\hline
\end{tabular}


A graphical analysis of the experimental results on water saturation over time is presented in Fig. 4, and for dehydration - in Fig. 5. It can be seen that the processes proceed according to a linear law and can be predicted for weakening the tuff-stone mined in a quarry.

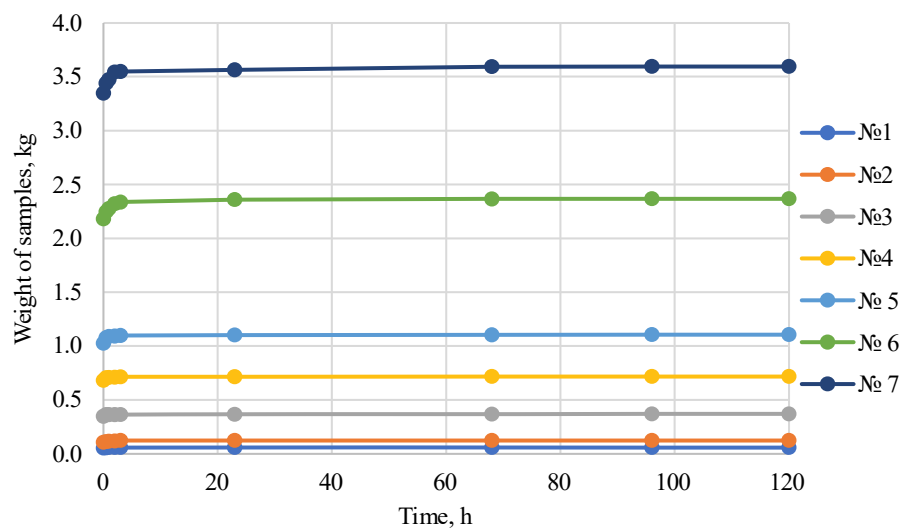

Fig. 4. Dependency graph of water saturation on the time of the tuff-stone with various weight.

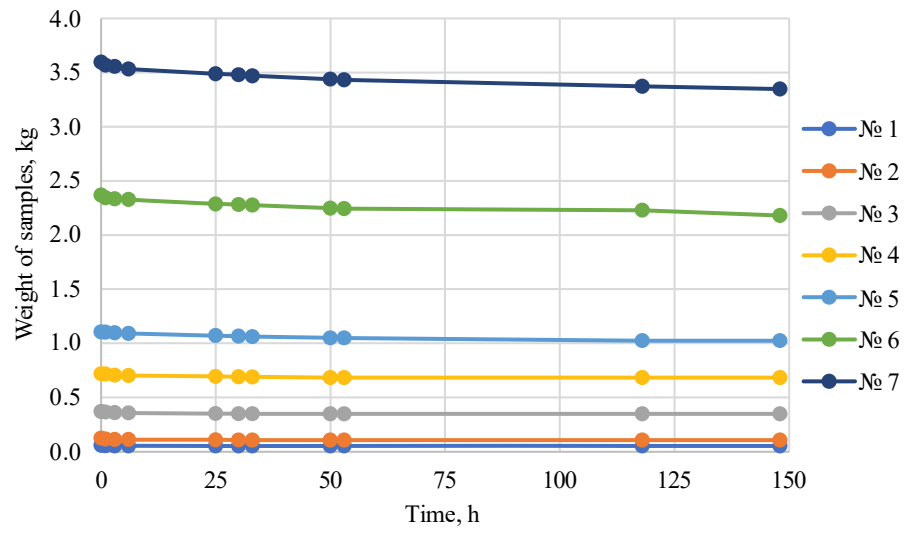

Fig. 5. Graph of dehydration over time of the tuff-stone with various weight.

The amount of water necessary for weakening is determined from the percentage moisture absorbed by the tuff-stone, which is at an average $10 \%$ of its weight during one cycle of wetting. Given the fact that when mining the basalts in a quarry, the underlying tuff-stone rocks are water-flooded and water from the quarry is periodically pumped out, it is enough to weaken the dump tuff-stone and this technology can be implemented at minimal cost.

In the presented research results, one cycle of the moisture influence on the tuff-stone has been studied. To reveal the tendency of its weakening under the influence of the following cycles of saturation and dehydration on the same samples, experiments were continued. The experimental results are presented in Table 4.

The results analysis has revealed that the saturation of the samples with water is the same in the weight ratio, however, in time it occurs more than by $40 \%$ faster than in the previous experiment. This is explained by an increase in the free surface and fracturing in the samples after the first experiment. A graphical analysis of the repeated samples saturation is shown in Fig. 6. 
Table 4. Results of the repeated tuff-stone samples saturation with water.

\begin{tabular}{|c|c|c|c|c|c|c|c|}
\hline \multirow{2}{*}{$\begin{array}{c}\text { Time, } \\
\text { hours }\end{array}$} & \multicolumn{7}{|c|}{ Sample weight, kg } \\
\cline { 2 - 8 } & № 1 & № 2 & № 3 & № 4 & № 5 & № 6 & № 7 \\
\hline 0 & 0.052 & 0.106 & 0.348 & 0.681 & 1.025 & 2.18 & 3.347 \\
\hline 0.5 & 0.057 & 0.114 & 0.358 & 0.704 & 1.077 & 2.25 & 3.448 \\
\hline 1 & 0.058 & 0.118 & 0.361 & 0.709 & 1.089 & 2.285 & 3.461 \\
\hline 2 & 0.058 & 0.12 & 0.363 & 0.712 & 1.092 & 2.342 & 3.477 \\
\hline 26 & 0.058 & 0.124 & 0.367 & 0.716 & 1.105 & 2.351 & 3.489 \\
\hline 49 & 0.058 & 0.125 & 0.369 & 0.718 & 1.106 & 2.36 & 3.547 \\
\hline 56 & 0.058 & 0.126 & 0.37 & 0.718 & 1.108 & 2.366 & 3.581 \\
\hline 84 & 0.058 & 0.126 & 0.371 & 0.718 & 1.11 & 2.366 & 3.594 \\
\hline
\end{tabular}

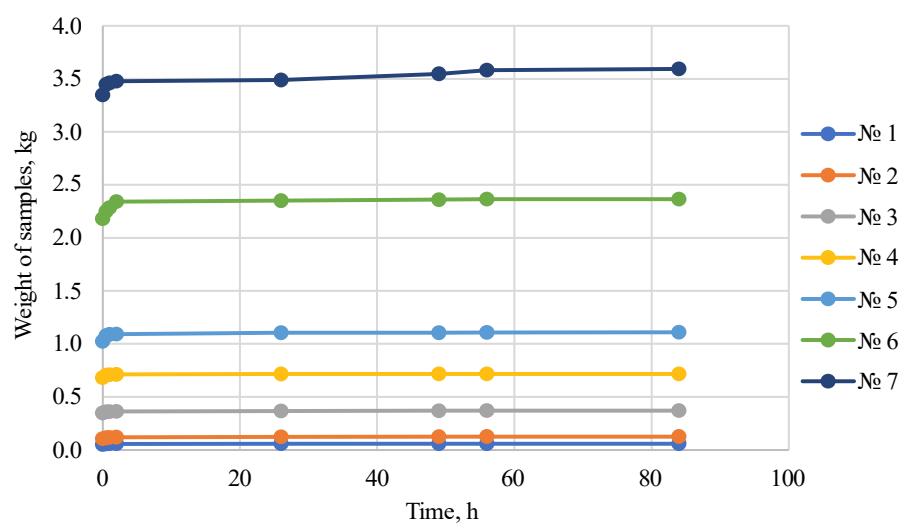

Fig. 6. Dependence on the time of the tuff-stone saturation in case of repeated wetting.

The reverse process of the samples dehydration also occurs much faster. The experimental results are presented in Table 5, and their graphical analysis is shown in Fig. 7. It can be seen that the dehydration process in the second case occurs more than by $30 \%$ faster. The reason for this acceleration is the samples break-down and an increase in the free surface area.

Table 5. Results of the repeated tuff-stone samples dehydration.

\begin{tabular}{|c|c|c|c|c|c|c|c|}
\hline \multirow{2}{*}{$\begin{array}{c}\text { Time, } \\
\text { hours }\end{array}$} & \multicolumn{7}{|c|}{ Sample weight, kg } \\
\cline { 2 - 8 } & № 1 & № 2 & № 3 & № 4 & № 5 & № 6 & № 7 \\
\hline 0 & 0.058 & 0.126 & 0.371 & 0.718 & 1.11 & 2.366 & 3.594 \\
\hline 1 & 0.053 & 0.119 & 0.366 & 0.716 & 1.105 & 2.348 & 3.552 \\
\hline 3 & 0.052 & 0.113 & 0.359 & 0.706 & 1.097 & 2.332 & 3.567 \\
\hline 6 & 0.052 & 0.113 & 0.354 & 0.702 & 1.09 & 2.327 & 3.518 \\
\hline 25 & 0.052 & 0.108 & 0.351 & 0.694 & 1.071 & 2.275 & 3.469 \\
\hline 68 & 0.052 & 0.106 & 0.341 & 0.679 & 1.039 & 2.24 & 3.413 \\
\hline 86 & 0.052 & 0.106 & 0.34 & 0.675 & 1.032 & 2.22 & 3.361 \\
\hline 110 & 0.052 & 0.106 & 0.34 & 0.675 & 1.025 & 2.16 & 3.347 \\
\hline
\end{tabular}

After repeated samples dehydration, the degree of their weakening is increased significantly. The fine fractions $(5-10 \mathrm{~mm})$ are broken down to sand size, while large ones increase lumpiness by $2-4$ times. Thus, for their complete destruction, several cycles are required for weakening according to the above methodology. This method allows selective destruction of the tuff-stone in the dump mass of a quarry and the technology development of its selective extraction from the total mass. 
Thus, water flooding of the tuff-stone dumps will weaken and reduce the lumpiness of the tuff-stone mass. The number of water flooding cycles should be selected experimentally, but not less than 2 are recommended.

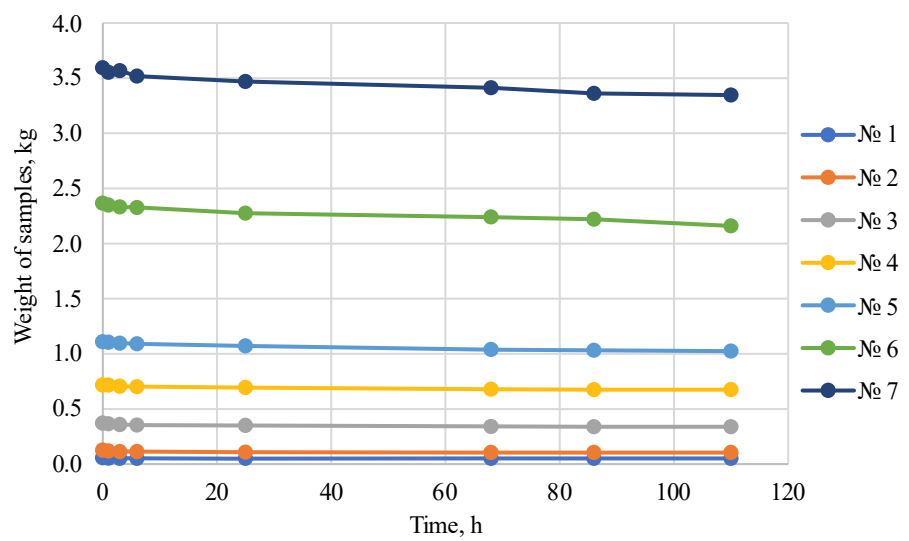

Fig. 7. Dependence on the time of the tuff-stone dehydration after repeated saturation with water.

The test results of the moisture influence on the tuff-stones in basalt quarries have revealed that this process is slower, depending on the periodicity of external moisture influence. It can be accelerated with additional water application. However, the tuff-stone in a composition with a quarry dump total mass, which consists of tuff breccia and insignificant part of basalt, has the most ground granulometric composition, but lavabreccia and basalt cannot bet destroyed by moisture. Therefore, after the tuff-stone is weakened and the dump rock mass is further exposed to vibratory screening for a fine size class $(2.0-2.5 \mathrm{~mm})$, selective extraction of the tuff-stone is possible. The research into such an extraction was conducted in the conditions of the Rafaiilovskyi basalt quarry in the fine classification section using a GIL-41 vibratory screen of serial production. It has been determined that up to $80 \%$ of the fine tuff-stone is in the screen underflow relative to its content in the loaded initial dump rock mass.

Thus, the research performed has shown that the tuff-stone extraction from the basalt quarry dumps is technologically possible with the use of periodic water application at certain sections with subsequent crushing and screening of the rock mass to recover the tuff-stone.

\section{Conclusions}

The research has determined that additional saturation with water allows weakening and decreasing the lumpiness of the tuff-stone mass, without decreasing the lumpiness of other rocks in the dump (lava-breccia, quartz, basalt). This makes it possible to perform selective tuff-stone extraction from the dump by fine vibratory screening.

To increase the production wells output in case of cyclic operation of wells, the tuffstones weakening by $10-15$ times under the influence of moisture should be taken into account. The amount of water supplied to the well should be with account of its absorption by the tuff-stone (at an average of $12 \%$ moisture relative to the dry weight of the samples).

As a result of the research performed, empirical mathematical dependences have been determined that make possible to predict the physical and mechanical tuff-stone properties, which are changed over time under the influence of saturation and dehydration. 
This work has been performed on the basis of the National University of Water Management Engineering (NUWME, Rivne) and with the participation of specialists from Rafalivskyj Kar'er, PAT (Rivne region, Volodymyrets district, Ivanchi). The authors express their gratitude to the rector of NUWME prof. V.S. Moshinsky for the opportunity to conduct research at the university's laboratory facilities and to the management of Rafalivskyj Kar'er, PAT, represented by Director P.P. Bortnik for the opportunity to conduct research into deep-lying tuff-stones and the tuff-stones in the Rafalivskyj quarry dumps.

\section{References}

1. Malanchuk, Z.R. Moshynskyi, V.S., Korniienko, V.Y., Malanchuk, Y.Z., \& Lozynskyi, V.H. (2019). Obgruntuvannia parametriv rozmyvu y peretikannia pulpy tseolit-smektytovoho tufu u vydobuvnii kameri. Naukovyi Visnyk NHU, (6), 11-18. (2019).

2. Nadutyi, V.P., \& Kostyrya, S.V. (2018). Research results on the process of complex puff-stone dehydration after underground hydraulic mining and dumping site working. Zbahachennia korysnykh kopalyn, 70(111), 58-63.

3. Ovchynnikov, M., Ganushevych, K., \& Sai, K. (2013). Methodology of gas hydrates formation from gaseous mixtures of various compositions. Annual Scientific-Technical Collection - Mining of Mineral Deposits, 203-205. https://doi.org/10.1201/b16354-37

4. Dreus, A.Yu., Sudakov, A.K., Kozhevnikov, A.A., Vakhalin, Yu.N. (2016). Study on thermal strength reduction of rock formation in the diamond core drilling process using pulse flushing mode. Naukovyi Visnyk Natsionalnoho Hirnychoho Universytetu, (3), 5-10.

5. Simarak, S., De Jong, U.W., Breslow, N., Dahl, C.J., Ruckphaopunt, K., Scheelings, P., \& Maclennan, R. (1977). Cancer of the oral cavity, pharynx/larynx and lung in North Thailand: case-control study and analysis of cigar smoke. British journal of cancer, 36(1), 130-140.

6. Lozynskyi, V., Medianyk, V., Saik, P., Rysbekov, K., \& Demydov, M. (2020). Multivariance solutions for about designing new levels of coal mines. Rudarsko Geolosko Naftni Zbornik, 35(2). Accepted paper. https://doi.org/10.17794/rgn.2020.2.3

7. Galiev, S.Z., Galiev, D.A., Seitaev, E.N., \& Uteshov, E.T. (2019). Unified methodology for management of a geotechnological complex in open pit mining. Gornyi Zhurnal, (12), 70-75. https://doi.org/10.17580/gzh.2019.12.15

8. Maldynova, A. (2018). Formation of marketing strategy for promoting an innovative product. Journal of Applied Economic Sciences, 13(7), 1951-1958.

9. Dychkovskyi, R., Vladyko, O., Maltsev, D., \& Cabana, E.C. (2018). Some aspects of the compatibility of mineral mining technologies. Rudarsko Geolosko Naftni Zbornik, 33(4), 73-82. https://doi.org/10.17794/rgn.2018.4.7

10. Uteshov, E.T. (2019). Digitalization and the potential for improving the design and planning of mining operations in open cast mining. News of the National Academy of Sciences of the Republic of Kazakhstan, Series of Geology and Technical Sciences, 1(439). 146-154.

11. Mambetov, S.A., Mambetov, A.S., \& Abdiev, A.R. (2002). Zonal and step-by-step evaluation of the stressed-strained state of Tyan'-Shan' rock mass. Gornyi Zhurnal, (10), 57-62.

12. Pivnyak, G., Bondarenko, V., Kovalevs'ka, I., \& Illiashov, M. (2012). Geomechanical Processes During Underground Mining, 238. Book. https://doi.org/10.1201/b13157

13. Khomenko, O.Ye. (2012). Implementation of energy method in study of zonal disintegration of rocks. Naukovyi Visnyk Natsionalnoho Hirnychoho Universytetu, (4), 44-54.

14. Gorova, A., Pavlychenko, A., \& Borysovs'Ka, O. (2013). The study of ecological state of waste disposal areas of energy and mining companies. Annual Scientific-Technical Collection - Mining of Mineral Deposits, 169-172. https://doi.org/10.1201/b16354-29

15. Buzylo, V., Pavlychenko, A., Savelieva, T., \& Borysovska, O. (2018). Ecological aspects of managing the stresssed-deformed state of the mountain massif during the development of multiple coal layers. E3S Web of Conferences, (60), 00013. https://doi.org/10.1051/e3sconf/20186000013 
16. Vladyko, O., Kononenko, M., \& Khomenko, O. (2012). Imitating modeling stability of mine workings. Geomechanical Processes During Underground Mining, 147-150. https://doi.org/10.1201/b13157-26

17. Chui, Y.V., Moshynskyi, V.S., Martyniuk, P.M., \& Stepanchenko, O.M. (2018). On conjugation conditions in the filtration problems upon existence of semipermeable inclusions. JP Journal of Heat and Mass Transfer, 15(3), 609-619. https://doi.org/10.17654/hm015030609

18. Kuzlo, M.T., Moshynskyi, V.S., Martyniuk, P.M. (2018). Mathematical modelling of soil mass's deformations under its drainage. International Journal of Applied Mathematics, 31(6), 751-762. https://doi.org/10.12732/ijam.v31i6.5

19. Moshynsky, V. (2001). Modern water conditions in the northwest part of Ukraine: An analysis. Water Engineering and Management, 148(4), 22-26

20. Kyrysha, R. (2018). Mathematical modelling of filtration processes in drainage systems using conformal mapping. Journal of Water and Land Development, 39(1), 11-15. https://doi.org/10.2478/jwld-2018-0054

21. Malanchuk, Z., Moshynskyi, V., Stets, S., Ignatiuk, I., \& Galiyev, D. (2020). Modelling hydraulic mixture movement along the extraction chamber bottom in case of hydraulic washout of the puffstone. E3S Web of Conference. Preprint.

22. Mikhlin, Y. V., \& Zhupiev, A. L. (1997). An application of the ince algebraization to the stability of non-linear normal vibration modes. International Journal of Non-Linear Mechanics, 32(2), 393-409. https://doi.org/10.1016/s0020-7462(96)00047-9

23. Saik, P.B., Dychkovskyi, R.O., Lozynskyi, V.H., Malanchuk, Z.R., \& Malanchuk, Ye.Z. (2016). Kharakterystyka pidzemnoi hazyfikatsii zapasiv vuhillia zblyzhenykh plastiv. Naukovyi Visnyk NHU, (6), 60-66.

24. Malanchuk, Z., Korniienko, V., \& Malanchuk, Ye. (2017). Results of research into amber mining by hydromechanical method. Mining of Mineral Deposits, 11(1), 93-99. https://doi.org/10.15407/mining11.01.093

25. Malanchuk, Z., Korniyenko, V., Malanchuk, Y., \& Khrystyuk, A. (2016). Results of experimental studies of amber extraction by hydromechanical method in Ukraine. Eastern-European Journal of Enterprise Technologies, 3(10(81)), 24. https://doi.org/10.15587/1729-4061.2016.72404

26. Malanchuk, Y., Korniienko, V., Moshynskyi, V., Soroka, V., Khrystyuk, A., Malanchuk, Z. (2019). Regularities of hydromechanical amber extraction from sandy deposits. Mining of Mineral Deposits, 13(1), 49-57. https://10.33271/mining13.01.049

27. Dryzhenko, A., Moldabayev, S., Shustov, A., Adamchuk, A., \& Sarybayev, N. (2017). Open pit mining technology of steeply dipping mineral occurences by steeply inclined sublayers. International Multidisciplinary Scientific GeoConference, 17(13), 599-606. https://doi.org/10.5593/sgem2017/13/s03.076

28. Stupnik, N., Kalinichenko, V., Pismennij, S., Kalinichenko, E. (2015). Features of underlying levels opening at "ArsellorMittal Kryvyic Rih" underground mine. New Developments in Mining Engineering 2015: Theoretical and Practical Solutions of Mineral Resources Mining, 39-44.

29. Levytskyi, V., Sobolevskyi, R., \& Korobiichuk, V. (2018). The optimization of technological mining parameters in a quarry for dimension stone blocks quality improvement based on photogrammetric techniques of measurement. Rudarsko Geolosko Naftni Zbornik, 33(2), 83-89. https://doi.org/10.17794/rgn.2018.2.8

30. Stupnik, M., Kolosov, V., Kalinichenko, V., Pismennyi, S. (2014). Physical modeling of waste inclusions stability during mining of complex structured deposits. Progressive Technologies of Coal, Coalbed Methane, and Ores Mining, 25-30. https://doi.org/10.1201/b17547

31. Cherniaiev, O.V. (2017). Systematyzatsiia nerudnykh rodovyshch skelnykh korysnykh kopalyn dlia vdoskonalennia tekhnolohii yikh vidpratsiuvannia. Naukovyi Visnyk NHU, (5), 11-17.

32. Sharapatov, A., Shayahmet, M., \& Arshamov, Y.K. (2016). About modern technology field geophysical research areas sulfide mineralization. News of the National Academy of Sciences of the Republic of Kazakhstan, Series of Geology and Technical Sciences, 1(415), 102-107. 
33. Sejtmuratova, E.J., Arshamov, J.K., Baratov, R.T., Dautbekov, D.O. (2016). Geological and metallogenic features of volcano-plutonic belt Kazakhstan. News of the National Academy of Sciences of the Republic of Kazakhstan, Series of Geology and Technical Sciences, 3(416), 60-86.

34. Arshamov, Y., Seitmuratova, E., \& Baratov, R. (2015). Perspectives of porphyry copper mineralizations in Zhongar-Balkhash fold system. International Multidisciplinary Scientific GeoConference Surveying Geology and Mining Ecology Management, 345-350.

35. Abdiev, A., Mambetova, R., Abdiev, A., \& Abdiev, Sh. (2020). Studying a correlation between characteristics of rock and their conditions. Mining of Mineral Deposits, 14(3), 87-100. https://doi.org/10.33271/mining14.03.087

36. Abdiev, A.R. (2002). Evaluation of the stressed-strained state of rock massif for brown coal deposit in Kara-Keche. Gornyi Zhurnal, (10), 70-72.

37. Abdiev, A.R., Mambetova, R.S., \& Mambetov, S.A. (2017). Geomechanical assessment of TyanShan's mountains structures for efficient mining and mine construction. Gornyi Zhurnal, (4), 2328. https://doi.org/10.17580/gzh.2017.04.04

38. Menshov, O., Kruglov, O., Vyzhva, S., Nazarok, P., Pereira, P., \& Pastushenko, T. (2018). Magnetic methods in tracing soil erosion. Studia Geophysica et Geodaetica, 62(4), 681-696. https://doi.org/10.1007/s11200-018-0803-1

39. Mulyavko, V.I., Oleynik, T.A., Oleynik, M.O., Mikhno, S.V., \& Lyashenko, V.I. (2014). Innovation technologies and machinery for separation of feebly magnetic ores. Obogashchenie Rud, (2), 43-49.

40. Gurin, A.A., Lyashenko, V.I., \& Taran, N.A. (2014). New technologies and means of tailings storage facilities dusting surface binding stabilization. Obogashchenie Rud, (5), 41-47.

41. Menshov, O., Spassov, S., Camps, P., Vyzhva, S., Pereira, P., Pastushenko, T., \& Demidov, V. (2020). Soil and dust magnetism in semi-urban area. Environmental Earth Sciences, (79), 1-10. https://doi.org/10.1007/s12665-020-08924-5

42. Seitmuratova, E., Arshamov, Y., Bekbotayeva, A., Baratov, R., \& Dautbekov, D. (2016). Priority metallogenic aspects of late paleozioc volcanic-plutonic belts of Zhongar-Balkhash fold system. International Multidisciplinary Scientific GeoConference Surveying Geology and Mining Ecology Management, (1), 511-518. https://doi.org/10.5593/sgem2016/b11/s01.064

43. Shashenko, A., Gapieiev, S., Solodyankin, A. (2009). Numerical simulation of the elastic-plastic state of rock mass around horizontal workings. Archives of Mining Sciences, 54(2), 341-348.

44. Bondarenko, V., Symanovych, G., \& Koval, O. (2012). The mechanism of over-coal thin-layered massif deformation of weak rocks in a longwall. Geomechanical Processes During Underground Mining, 41-44. https://doi.org/10.1201/b13157-8

45. Baibatsha, A., Arshamov, Y., Bekbotayeva, A., \& Baratov, R. (2017). Geology of the main industrial types of copper ore deposits in Kazakhstan. International Multidisciplinary Scientific GeoConference, Science and Technologies in Geology, Exploration and Mining, 17(11), 231-238. https://doi.org/10.5593/sgem2017/11/s01.029

46. Malanchuk, Z., Moshynskyi, V., Malanchuk, Y., \& Korniienko, V. (2018). Physico-Mechanical and Chemical Characteristics of Amber. Solid State Phenomena, (277), 80-89. https://doi.org/10.4028/www.scientific.net/ssp.277.80

47. Malanchuk, Y., Moshynskyi, V., Korniienko, V., \& Malanchuk, Z. (2018). Modeling the process of hydromechanical amber extraction. E3S Web of Conferences, (60), 00005. https://doi.org/10.1051/e3sconf/20186000005

48. Malanchuk, Z., Moshynskyi, V., Malanchuk, V., Korniienko, Y., \& Koziar, M. (2020). Results of Research into the Content of Rare Earth Materials in Man-Made Phosphogypsum Deposits. Key Engineering Materials, (844), 77-87.

49. Naduty, V., Malanchuk, Z., Malanchuk, E., \& Korniyenko, V. (2015). Modeling of vibro screening at fine classification of metallic basalt. New Developments in Mining Engineering, 441443. https://doi.org/10.1201/b19901-77

50. Naduty, V., Malanchuk, Z., Malanchuk, Y., \& Korniyenko, V. (2016). Research results proving the dependence of the copper concentrate amount recovered from basalt raw material on the 
electric separator field intensity. Eastern-European Journal of Enterprise Technologies, 5(5(83)), 19-24. https://doi.org/10.15587/1729-4061.2016.79524

51. Malanchuk, Z., Korniienko, V., Malanchuk, Ye., Soroka, V., \& Vasylchuk, O. (2018). Modeling the formation of high metal concentration zones in man-made deposits. Mining of Mineral Deposits, 12(2), 76-84. https://doi.org/10.15407/mining12.02.076 